\title{
Modes de consommation et manières de table dans les Alpes du sud
}

\section{Christine Escallier}

\section{(2) OpenEdition \\ 12 Journals}

Édition électronique

URL : https://journals.openedition.org/tc/394

DOI : $10.4000 /$ tc.394

ISSN : 1952-420X

Éditeur

Éditions de l'EHESS

Édition imprimée

Date de publication : 1 avril 1999

ISSN : 0248-6016

Référence électronique

Christine Escallier, "Modes de consommation et manières de table dans les Alpes du sud ",

Techniques \& Culture [En ligne], 31-32 | 1999, mis en ligne le 26 octobre 2005, consulté le 29 septembre 2022. URL : http://journals.openedition.org/tc/394 ; DOI : https://doi.org/10.4000/tc.394

Ce document a été généré automatiquement le 29 septembre 2022.

Tous droits réservés 
Modes de consommation et manières de table dans les Alpes du sud

Christine Escallier 